\title{
IRRIGATION MANAGEMENT IN SOYBEAN CROPS INFLUENCES THE OCCURRENCE OF NEMATODES IN THE SOIL
}

\author{
MANEJO DE IRRIGAÇÃO NA CULTURA DA SOJA INFLUENCIA A OCORRÊNCIA \\ DE NEMATOIDES NO SOLO
}

\author{
Ricardo GAVA ${ }^{1}$; Thiago Ramos da SILVA ${ }^{1}$; Mayara Fávero COTRIM²; \\ Alexandra Botelho Lima ABREU ${ }^{3}$; Jefferson Luis ANSELMO ${ }^{4}$; Paulo Eduardo TEODORO ${ }^{1 *}$ \\ 1. Universidade Federal de Mato Grosso do Sul, Chapadão do Sul, MS, Brasil; 2. Universidade Estadual Paulista "Julio de Mesquita \\ Filho", Ilha Solteira, SP, Brasil; 3. FMC Corporation, Chapadão do Sul, MS, Brasil; 4. Fundação de Apoio a Pesquisa Agropecuária de \\ Chapadão, Chapadão do Sul, MS, Brasil. *eduteodoro@hotmail.com
}

\begin{abstract}
One of the main limitations of soybean production is related to water availability and organisms found in the soil. Under the hypothesis that soil moisture may influence the nematode population, this study aimed to verify the occurrence of nematodes associated with different irrigation management in soybean crops. The experiment was carried out in a randomized block design. Treatments consisted of a subplot scheme, with four replications. The plots consisted of ten irrigation managements divided into five irrigation frequencies $(1,2,3,4$, and 5 days) and five additional water depths $(25,50,75,100$, and 125\% of crop evapotranspiration - Etc). The subplots were composed of four different soybean cultivars (NA 5909 RR, AS 3680 IPRO, and Desafio RR ePower IPRO). The experiment analyzed the variables plant height, first pod insertion, number of plants, moisture, hundred-grain weight, yield, and occurrence of nematode eggs and adults. Nematodes influence all the production components analyzed, affecting mostly the hundred-grain weight, especially the nematode Helicotylenchus sp., although the Meloidogyne sp. population was larger. The phytonematode population reduces with the increase in soil moisture to levels close to the saturation, indirectly influencing the yield increase.
\end{abstract}

KEYWORDS: Phytonematode. Glycine Max L. Water depths.

\section{INTRODUCTION}

Brazil and Argentina account for $50 \%$ of world soybean production and exports (FAO, 2017). Soybean is widely used in human and animal diet, and thus, it has great economic relevance. The high yield potential achieved by soybean crop is mostly due to the constant search for new technological solutions.

In the 2016/2017 season, grain crops were cultivated in 60.9 million hectares, which accounted for the largest area intended to grain crops in Brazilian history (CONAB, 2018). This area is concentrated in soybean and maize crops, corresponding to $85 \%$ of the total área cultivated with grains in the country. However, one of the main limiting causes of global agricultural production is the occurrence of pests and diseases. In this context, phytonematodes are one of the most important pests due to their difficult control (DIAS-ARIEIRA, 2011). In soybean crops, nematodes can be found both in the soil and plant roots and may cause severe damage to the crop. According to Inomoto (2006), the most common nematode genera found in Brazilian soybean crops are Meloidogyne javanica, $M$.
Icognita, and M. Arenaria (the root-knot nematodes); Heterodera glycines (the soybean cyst nematode - SCN); Rotylenchulus reniformis; and Pratylenchus brachyurus (the lesion nematode). These species have been observed in different Brazilian regions, mostly in the Central region, where the problem has increased, causing severe damages in soybean crops in the stated of Mato Grosso do Sul and Goias (EMBRAPA, 2011).

Abreu \& Borges (2016) studied the region between the states of Mato Grosso, Goiás, and Mato Grosso do Sul and reported the lesion nematodes (Pratylenchus brachyurus) in most samples $(74 \%$ in the 2014/15 season). The root-knot nematodes (Meloidogyne javanica, Meloidogyne icognita, Meloidogyne arenaria) and the soybean-cyst nematode (Heterodera glycines) were also found in the samples. Heterodera glycines was found in larger number in the 2015/16 season when compared with previous seasons.

The soil moisture between 40 and $60 \%$ of the field capacity is considered as optimal for the nematode activity. Greater populations are usually found in moist and well-aerated soils, while saturated soils are usually unfavorable to nematode activity (LAUGHLIN; LORDELLO, 1977). The 
nematodes control in the soil associated with irrigation is a viable alternative for producers since the population of several phytonematodes species is significantly reduced due to oxygen limitation and soil pH (MASSAROTO \& YAMASHITA, 2011). This study aimed to assess the occurrence of nematodes in soybean crops under different irrigation management.

\section{MATERIAL AND METHODS}

The experiment was carried out at Fundação de Apoio à Pesquisa Agropecuária de Chapadão, located in the municipality of Chapadão do Sul, MS (lat. 1846'49 "S; long. 52³8'51"W; alt. $810 \mathrm{~m}$ asl.) after three harvests of the soybean and maize production system, under center pivot. According to the Köppen classification (PEEL et al., 2007), the climate of the region is Aw type (tropical with dry winter and rainy summer), with an average annual temperature of $25^{\circ} \mathrm{C}$ and an average annual rainfall of $1800 \mathrm{~mm}$. The soil was classified as Clayey Dystrophic Red Latosol and the physical and water characteristics required for the correct irrigation management were obtained (Table 1).

Table 1. Physical and water characteristics of the soil

\begin{tabular}{|c|c|c|c|c|c|c|c|c|c|c|}
\hline \multirow{2}{*}{$\begin{array}{c}\text { Layer } \\
(\mathrm{cm})\end{array}$} & \multirow{2}{*}{$\frac{F C}{(\mathrm{~cm}}$} & PWP & \multirow{2}{*}{$\begin{array}{c}\text { WCA } \\
\left(\mathrm{mm} \mathrm{cm}^{-1}\right)\end{array}$} & $\rho$ & Pd & \multirow{2}{*}{$\begin{array}{l}\text { TP } \\
(\%)\end{array}$} & \multicolumn{3}{|c|}{ Granulometric fractions } & \multirow[t]{2}{*}{ Texture } \\
\hline & & $\left.m^{-3}\right)$ & & \multicolumn{2}{|c|}{$\left(\mathrm{g} \mathrm{cm}^{-3}\right)$} & & Sand & Silt & Clay & \\
\hline $\begin{array}{c}0-15 \\
15-30\end{array}$ & $\begin{array}{l}0.413 \\
0.383\end{array}$ & $\begin{array}{l}0.282 \\
0.262\end{array}$ & $\begin{array}{l}1.76 \\
1.74\end{array}$ & $\begin{array}{l}1.34 \\
1.44\end{array}$ & $\begin{array}{l}2.65 \\
2.65\end{array}$ & $\begin{array}{l}53.6 \\
48.4\end{array}$ & $\begin{array}{l}39.24 \\
36.76\end{array}$ & $\begin{array}{l}6.68 \\
4.56\end{array}$ & $\begin{array}{l}54.08 \\
58.68\end{array}$ & Clayey \\
\hline
\end{tabular}

FC - Moisture in the field capacity at the matric potential $\left(\Psi_{\mathrm{m}}\right)$ of $0.3 \mathrm{~atm}$; PWP - Permanent wilting point in $\Psi_{\mathrm{m}}$ of 15 atm; WCA available water capacity; $\rho$ - Soil bulk density; TP - total soil porosity; Pd- Soil particle density

Soybean seeds were treated with fungicide (Pyraclostrobin) and insecticide (Fipronil) at a dose of $200 \mathrm{~mL}$ per $100 \mathrm{~kg}$ of seeds. Seeds were sown on October 19, 2016, in a no-tillage system, with a spacing of $0.45 \mathrm{~m}$ between rows. Plots were composed of five sowing rows. The useful area consisted of the three central rows $\left(3,6 \mathrm{~m}^{2}\right)$.

Fertilization consisted of $150 \mathrm{~kg} \mathrm{ha}^{-1}$ of NPK (11-52-00) applied in the sowing row, and 150 $\mathrm{kg} \mathrm{ha}^{-1}$ of $\mathrm{KCl}$ applied as topdressing. The irrigation frequencies were 1, 2, 3, 4 and 5 days, calculated by the Crop Evapotranspiration (Etc) accumulated in the interval between irrigations. The water depths
$(25,50,75,100$, and $125 \%$ of ETc) were applied only when the crop reached the lower limit of the actual soil water capacity (ASWSC) (ALLEN et al., 1998). The experiment was carried out in a complete randomized block design, in a subplot scheme. The central pivot was divided into ten plots (five irrigation frequencies and five additional water depths), with four replications. The plots were subdivided into four subplots, where the different soybean cultivars were planted (NA 5909 RR (C1), AS 3680 IPRO (C2), Desafio RR (C3) e POWER IPRO (C4) (Table 2).

Table 2. Plant population and soybean cycle.

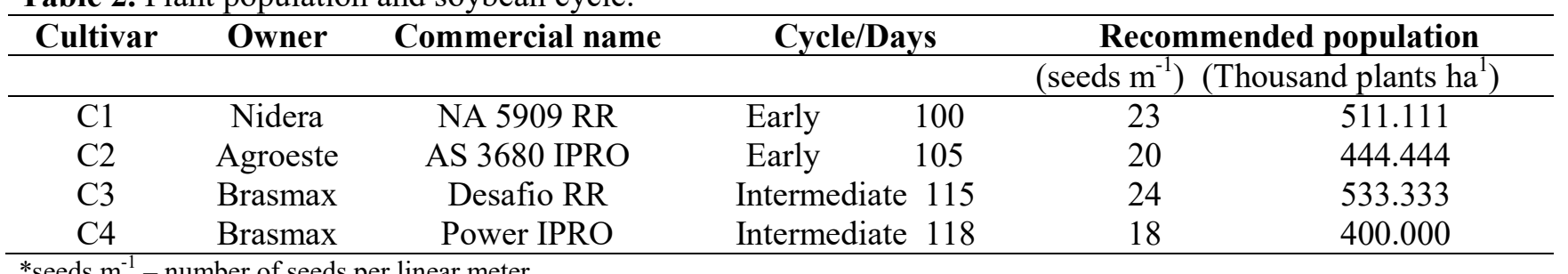

*seeds $\mathrm{m}^{-1}-$ number of seeds per linear meter

Table 3 shows the number of irrigations, total water depth applied per treatment, and the accumulated ETc in the period. Since the experiment was carried out in the field, some rainfall events were registered, which hindered the effect of the treatments that went through larger intervals without irrigation.
The ETo was obtained by the PenmanMonteith-FAO method, according to Allen et al. (1998), using data from the automatic meteorological station of the Instituto Nacional de Meteorologia (INMET), located in the municipality of Chapadão do Sul, MS, Brazil. The ETc was obtained by multiplying the Reference 
Evapotranspiration (ETo) by the Crop Coefficient $(\mathrm{Kc})$. The crop coefficients and the root system depth of each subperiod were defined according to the recommendations of Doorenbos \& Kassam (1994).

Table 3. Number of irrigations, total water depth applied and accumulated evapotranspiration of treatments.

\begin{tabular}{cccc}
\hline Treatments & Number of irrigations & $\begin{array}{c}\text { Total water depth } \\
\text { applied } \\
\text { mm }\end{array}$ & Accumulated ETc \\
\hline 1 day & \multicolumn{2}{c}{ Frequency } & 176 \\
$\mathbf{2}$ days & 36 & 123 & \\
$\mathbf{3}$ days & 13 & 103 & 370 \\
$\mathbf{4}$ days & 8 & 111 & \\
$\mathbf{5}$ days & 7 & 65 & \\
\hline $\mathbf{2 5}$ & 4 & & \\
$\mathbf{5 0}$ & Water Depth (\% ETc) & 26 & \\
$\mathbf{7 5}$ & 5 & 46 & \\
$\mathbf{1 0 0}$ & 5 & 66 & \\
$\mathbf{1 2 5}$ & 5 & 86 & \\
\hline
\end{tabular}

The variable plant height $(\mathrm{PH})$ was analyzed by measuring the distance from the soil and the end of the main stem. First pod insertion (FPI) was analyzed by measuring the distance from the soil and the first pod. Number of plants (NP) was determined by counting all the plants. Hundredgrain weight (HGW) was determined by weighing one hundred grains. Grain yield (Y) was analyzed by harvesting the central rows of the plot, totaling $3.6 \mathrm{~m}^{2}$ of experimental area. HGW and Y obtained had their results corrected to $13 \%$ of moisture (storage standard), determined by an electronic sampler at the evaluation time.

For the nematological evaluation, samples were collected at three different points within each subplot to compose one single sample per treatment, totaling 160 samples. Samples were collected when cultivars were at full bloom (EMBRAPA, 2009). The analyses were carried out by separating the roots to remove $100 \mathrm{~cm}^{3}$ of the soil used for nematode extraction, followed by the sieving and centrifugal flotation processes (JENKINS, 1964). Roots were washed, and $10 \mathrm{~g}$ were used the nematodes extraction, followed by the trituration, sieving, and centrifugation (COOLEN \&D'HERDE, 1972). Nematodes were counted with the aid of the
Peters Chamber, under a light microscope, for the identification and quantification of specimens.

The means of each treatment were subjected to the principal component analysis to verify the interrelationship between the production components and their association with the treatments. For data analysis, the Pearson's correlations between the production components were estimated. The functional relationship between the estimates of coefficients of correlation among the traits was graphically expressed by a correlation network, where the proximity between the nodes (traces) is proportional to the absolute value of the correlation between these nodes. The thickness of the edges was controlled by applying a cut-off value of 0.60 , which means that only $\left|\mathrm{r}_{\mathrm{ii}}\right| \geq 0.60$ have their edges highlighted. Positive correlations were highlighted in green, and negative correlations were highlighted in red. All analyses were carried out using the Rbio software (BHERING, 2017).

\section{RESULTS AND DISCUSSION}

Results of the water balance (WB) of the experimental period revealed two moments when the soil moisture surpassed the lower limit of readily 
available water, given by the ASWSC (Figure 1). The first moderate deficit occurred between 55 and 67 DAE (days after emergence) in early cultivars at the phenological stage R5.1, and in late cultivars, at the stage R4. The second moderate deficit occurred at the end of the cycle, between 126 and 131 DAE, when the early cultivars had already completed their cycles, and the late cultivars were at the final stage of grain filling.

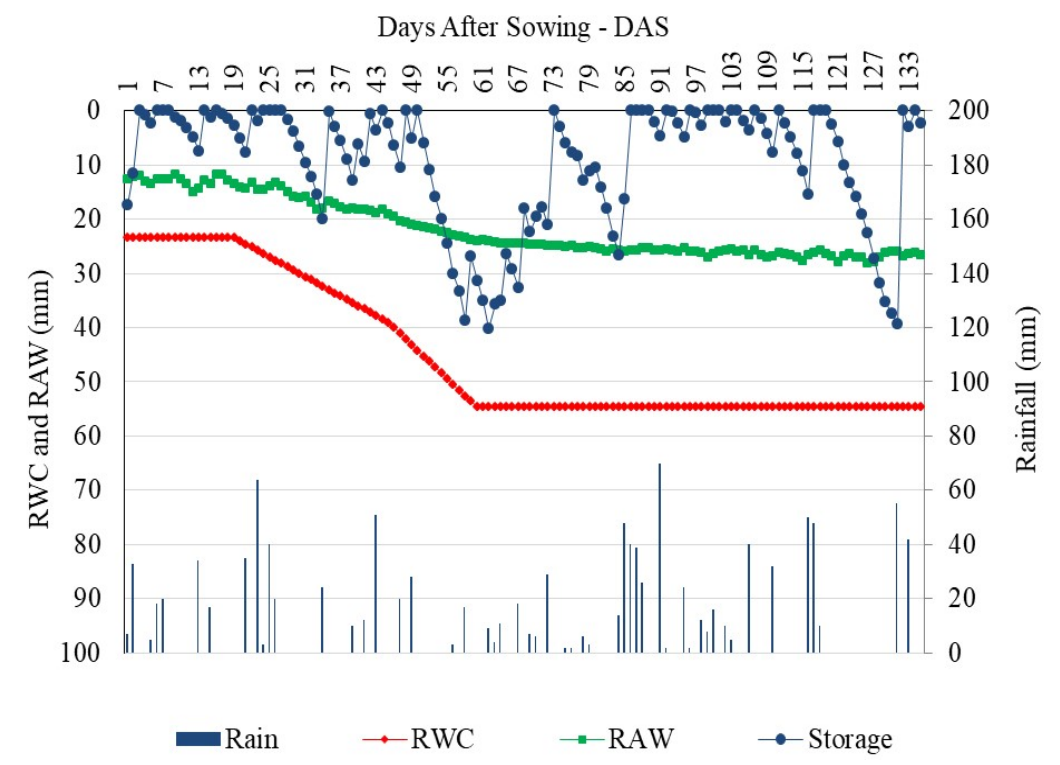

Figure 1. Rainfall at the experimental area, residual water content (RWC), readily available water (RAW), and soil water storage (Storage).

Figure 1 shows the soil moisture variation in millimeters, indicated by the Storage line; the AWC values ranged according to the development of the root system, stabilizing at $54.7 \mathrm{~mm}$, at the effective depth of $0.35 \mathrm{~m}$, established at the end of the vegetative stage (Allen et al., 1998).

The principal component analysis confirmed the accumulation of $71 \%$ of the total observed variability (Figure 3). Both irrigations with an interval of one and two days increased HGW and Y, respectively, demonstrating that high frequencies irrigations directly correlated with the principal components. Due to the high incidence of rainfall over the crop cycle, the plants' acclimatization was mostly subject to cloudy days with high humidity; therefore, treatments with high irrigation frequency resembled the actual conditions to which the plant was subject.

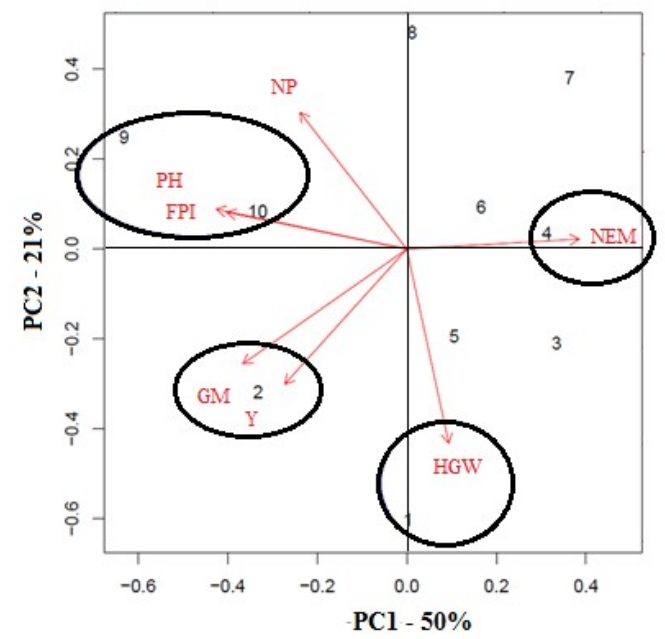

Figure 2. Principal components analysis for the variables plant height (PH), first pod insertion (FPI), number of plants (NP), grain moisture (GM), hundred-grain weight (HGW), nematode (NEM), and yield (Y) evaluated in different irrigation managements. 
Among the water depths, levels 9 and 10 increased PH and FPI. Conversely, the higher occurrence of nematodes was observed in larger intervals and smaller water depths, considered to be favorable to the growth and emergence of nematodes in general. Laughlin \& Lordello, (1977) confirm that the soil moisture between 40 and $60 \%$ of the field capacity is considered as optimal for nematodes activity and that saturated soils impair the growth of the nematode. Therefore, the high soil moisture reduced the nematodes, indirectly influencing yield. Negretti et al. (2014) studied rice crops under irrigation system and observed the reduction in the nematodes reproduction and number of root-knot for other genera of nematodes (A. philoxeroides, O. sativa -ARV, E. crusgalli, $C$. difformis, $C$. iria, and $F$. miliacea)

The correlation analysis revealed that cultivars C3 and C4 influenced yield. The different managements tested showed similar yield results, which can be explained by the water balance of the period (large amount of rainfall and small numbers of irrigations). Conversely, FPI and NP are directly related to cultivar C4. Brida et al. (2017) explain that the nematode $P$. brachyurus can penetrate and grow in roots regardless of the soybean cultivar analyzed. Matsuo et al. (2012) and Bellé et al. (2017) found differences between soybean and sugarcane genotypes, respectively, and classified them as resistant and moderately resistant to Heterodera glycines, Meloidogyne javanica, and Pratylenchus zeae, respectively.

The $\mathrm{PH}$ and $\mathrm{HGW}$ had a high negative correlation (Figure 3), indicated by the thick red line, showing that the taller the plants, the lower was the value of hundred-grain weight. Conversely, FPI and NP showed a positive correlation of high magnitude, indicated by the green line, indicating that the larger the plant population, the higher was the first pod insertion.

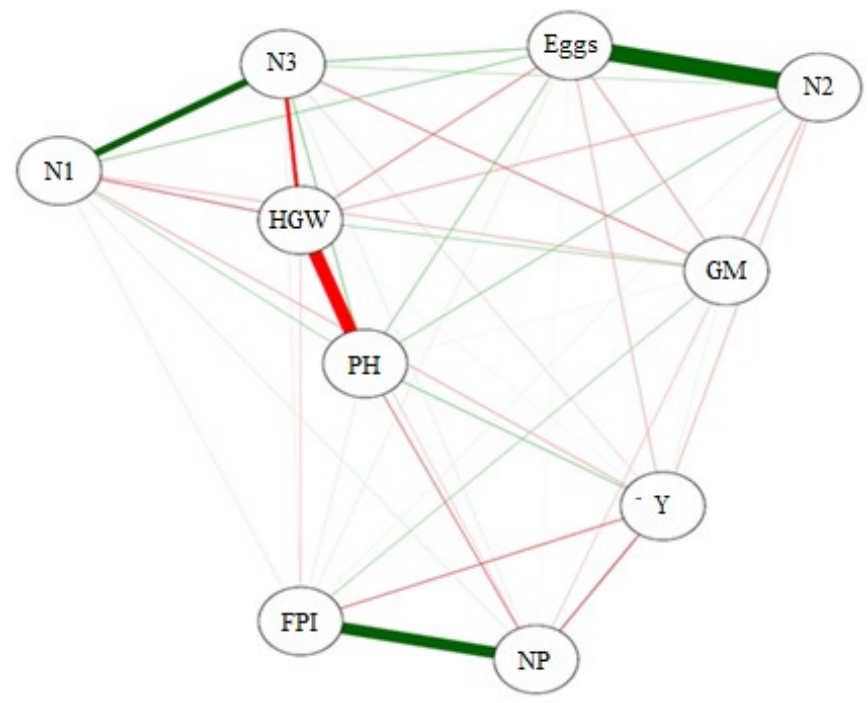

Figure 3. Correlation network between different irrigation managements for plant height $(\mathrm{PH})$, first pod insertion (FPI), number of plants (NP), grain moisture (GM), hundred grain weight (HGW), yield (Y), nematode eggs, and nematodes population [Pratylenchus brachyurus (N1), Meloidogyne sp. (N2), and Helicotylenchus sp. (N3)]. Positive correlations were highlighted in green, and negative correlations were highlighted in red; the thickness of the traces indicates the magnitude of the correlation.

Nematodes negatively influenced all the yield components. According to Dias (2011), the implantation of the no-tillage system requires great caution in choosing the successor crop, and most of the soybean areas are succeeded by maize. Therefore, both soybean and maize crops are highly susceptible to P. Brachyurus. The occurrence of Helicotylenchus $s p$ (N4) interfered with HGW. According to Garbin \& Costa (2015), low rainfall rates are associated with high incidence of Helicotylenchus $s p$. in the soil and roots. This species is associated with most soil analyses carried out under conditions similar to that of the state of Mato Grosso. Thus, studies on damages and losses require attention. The eggs (N1) showed a strong and positive correlation with the genus Meloidogyne $s p$. (N3), suggesting a higher occurrence of this species. Fontana et al. (2018) state that Meloidogyne $s p$. eggs are protected from natural enemies and from the lack of moisture by the egg amount secreted by females. This is not the case of 
Pratylenchus brachyurus eggs, which are deposited in the soil.

\section{CONCLUSIONS}

Nematodes influence all the yield components analyzed. Hundred-grain weight is primarily affected, mainly by the nematode Helicotylenchus sp., although the population of Meloidogyne sp. is larger.

The phytonematode population reduces with the increase in the soil moisture to levels close to saturation, indirectly increasing yield.

RESUMO: Uma das principais limitações da produção de soja está relacionada à disponibilidade de água e organismos encontrados no solo. Sob a hipótese de que a umidade do solo possa influenciar a população de nematoides, este estudo teve como objetivo verificar a ocorrência de nematóides associados a diferentes manejos de irrigação em lavouras de soja. O experimento foi conduzido em delineamento de blocos casualizados. Os tratamentos consistiram de um esquema de subparcelas, com quatro repetições. As parcelas consistiram de dez manejos de irrigação divididos em cinco freqüências de irrigação $(1,2,3,4$ e 5 dias) e cinco lâminas d'água $(25,50,75,100$ e $125 \%$ da evapotranspiração da cultura - Etc). As subparcelas foram compostas por quatro diferentes cultivares de soja (NA 5909 RR, AS 3680 IPRO e Desafio RR ePower IPRO). $\mathrm{O}$ experimento analisou as variáveis altura da planta, inserção da primeira vagem, número de plantas, umidade, peso de cem grãos, produtividade e ocorrência de ovos de nematoides e adultos. Os nematóides influenciam todos os componentes de produção analisados, afetando principalmente o peso de cem grãos, especialmente o nematódeo Helicotylenchus sp., Embora o Meloidogyne sp. população era maior. A população de fitonematóides reduz com o aumento da umidade do solo para níveis próximos à saturação, influenciando indiretamente o aumento da produtividade.

PALAVRAS-CHAVE: Fitonematodes. Glycine Max L. Lâminas de água.

\section{REFERENCES}

ALLEN, R.G.; PEREIRA, L.S.; RAES, D.; SMITH, M. Crop evapotranspiration.Rome: FAO, 1998. 301, p. (FAO. Irrigation Paper, 56).

ABREU, A. B. L.; BORGES, E. P. Levantamento de Nematoides na Região dos Chapadões e Metodologia para Coleta de Material para Análise. Pesquisa - Tecnologia - Produtividade/ Safra 2016/17 Soja e Milho, v.1, p.112-115, 2017.

BELLÉ, C.; KULCZYNSKI, S. M.; KUHN, P. R.; DONINI, L. P.; GOMES, C. B. Reacção de genótipos de cana-de-açúcar em parasitas de Meloidogyne javanica E Pratylenchus zeae. Rev. Caatinga, v.30, n.2, 2017. https://doi.org/10.1590/1983-21252017v30n229rc

BHERING, L.L. RBIO: A Tool For Biometric And Statistical Analysis Using The R Platform. Crop Breeding and Applied Biotechnology, v.17: 187-190, p. 2017. https://doi.org/10.1590/1984-70332017v17n2s29

BRIDA, A. L.; CORREIA, E. C. S. S.; WILCKEN, S. R. S. Suscetibilidade de cultivares de soja ao nematoide das lesões radiculares. Summa phytopathol, v.43, n.3, 2017. https://doi.org/10.1590/0100-5405/2177

COMPANHIA NACIONAL DE ABASTECIMENTO - CONAB. Acompanhamento da Safra Brasileira Grãos, v.4 Safra 2016/17 - Décimo segundo levantamento, Brasília, p. 1-158 Setembro 2018.

COOLEN, W.A.; D'HERDE, C.J. A method for the quantitative extraction of nematodes from plant tissue. Ghent: State Nematology and Entomology Research Station, 1972. 77p.

DIAS-ARIEIRA,C.R;SANTANA,S.M.;CHIAMOLERA,F.M. Manejo de sustentável de fitonematoides no Brasil. In: XXIX Congresso Brasileiro de Nematologia, 2011, Brasilia. Anais XXIX Congresso Brasileiro de Nematologia. Brasileira, DF: Sociedade Brasileira de Nematologia, 2011, p.41-46 
DOORENBOS, J.; KASSAM, A.H. Efeito da água no rendimento das culturas. Campina Grande: UFPB; FAO, 1994. 306p. (FAO. Estudos: Irrigação e Drenagem, 33).

EMBRAPA. EMPRESA BRASILEIRA DE PESQUISA AGROPECUÁRIA. Coleta de Amostras para Análise de Nematoides: recomendações gerais / Alexandre Moura Cintra Goulart. - Planaltina, DF : Embrapa Cerrados, 2009. 31 p. - (Documento / Embrapa Cerrados, ISSN 1517-5111, ISSN online 2176-5081 ; 255).

EMBRAPA. EMPRESA BRASILEIRA DE PESQUISA AGROPECUÁRIA. Tecnologias de produção de soja- Região Central do Brasil 2012 e 2013. Centro Nacional de Pesquisa de Soja. Londrina-PR: Embrapa Soja, 2011, 261 p. (Sistemas de Produção, 15).

FAO - Food and Agriculture Organization of the United Nations. Soybean prices, economic growth and poverty in Argentina and Brazil. 2017. Disponível em: $<$ http://www.fao.org/3/i8316en/I8316EN.pdf $>$. Acesso em: 08 out. 2018.

FONTANA, L. F.; ARIEIRA, C. R. D.; ABE, V. H. F.; SEVERINO, J. J.; ARIEIRA, J. O.; MONTEIRO, R. N. F. Interferência de Meloidogyne javanica na reprodução de Pratylenchus brachyurus em cultivares de soja BRS / MT. Summa phytopathol,v.44, n.2, 2018. https://doi.org/10.1590/0100-5405/177037

HAIR, J. F., et al. Análise multivariada de dados. Trad. Adonai S. Sant'Anna e Anselmo C. Neto. 5 ed. Porto Alegre: Bookman, 2005.

INOMOTO, M. M; MOTTA, L. C. C.; BELUTI, D. B. Reação de seis adubos verdes a Meloidogyne javanica e Pratylenchus brachyurus. Nematologia Brasileira, Brasília, v. 30, n. 1, p.39-44, 2006.

JENKINS, W.R. A rapid centrifugal-flootation technique for separating nematodes from soil. Plant Disease Reporter, Beltisville, v. 48, n. 9, p.692, 1964.

KUBRUSLY, L. S. Um procedimento para calcular índices a partir deuma base de dadosmultivariados. Pesquisa Operacional, Rio de Janeiro, v.21, n. 1, 2001. https://doi.org/10.1590/S0101-74382001000100007

LAUGHLIN, C.W., LORDELLO, L.G. Sistemas de manejo de nematoides: Relação entre a densidade de população e os danos à planta. II Reunião de Nematologia, 15-24, 1977.

MALHOTRA, N. Pesquisa de marketing: uma orientação aplicada. Trad. Laura Bocco. 4 ed. Porto Alegre: Bookman, 2006.

MASSAROTO, J. G.; YAMASHITA, O. M. Propriedades do solo relacionadas a inundação para o controle de fitonematoides. Revista de Ciências Agro-Ambientais, Alta Floresta, v.9, n.1, p.153-163, 2011.

MATSUO, E.; SEDIYAMA, T.; OLIVEIRA, R. D. L.; CRUZ, C. D.; OLIVEIRA, R. C. T. Avaliação de genótipos de soja em relação ao nematoide de cisto. Bragantia, v.71, n.2, 2012. https://doi.org/10.1590/S000687052012005000016

NEGRETTI, R.R.D.I; MANICA-BERTO, R.; AGOSTINETTO, D.; THÜRMER, L.; GOMES, C.B. Host suitability of weeds and forage species to root-knot nematode Meloidogyne graminicola as a funcion of irrigation management. Planta daninha, v.32, n.3, 2014. https://doi.org/10.1590/S0100-83582014000300011

PEEL, M.C.; FINLAYSON, B.L.; McMAHON, T.A. Updated world map of the Köppen-Geiger climate classification. Hydrology and Earth System Sciences Discussions, European Geosciences Union, 2007, v. 4, n. 2, p. 439-473. https://doi.org/10.5194/hessd-4-439-2007 